Maria Sabaté Dalmau*

\title{
Migrants' alternative multi-lingua franca spaces as emergent re-producers of exclusionary monolingual nation-state regimes
}

DOI 10.1515/multi-2014-0097

Abstract: From a critical sociolinguistic perspective, this article investigates the written linguistic practices of 20 labor migrants from heterogeneous backgrounds who organized their life trajectories in an 'ethnic' call shop in a marginal neighborhood near Barcelona. This was a late capitalist institution informally providing the undocumented with survival resources off the radar from governmental authorities. By drawing on interviews and visual materials gathered over a two-year fieldwork project, I report on the amalgamations of allochthonous and autochthonous codes which function as the multi-lingua franca of these alternative shelters, which have now colonized the globalized urban landscape. I argue that these translinguistic practices speak of the ethnolinguistic identities with which migrants try to secure subsistence. I show, though, that transnational populations simultaneously map their in-group codes upon a unified floor where the use of only global Spanish is fostered. Users sanction their linguistic hybridity and self-correct into hegemonic standard norms which index 'integration' and fully-fledged citizenship statuses, delegitimizing their linguistic capitals. I conclude that the migrants' grassroots mobilization of both linguistic resistance and regimentation within a single discursive space where exclusionary sociolinguistic orders could be contested uniquely unveils the ways in which they challenge, but paradoxically re-produce, the monolingual nation-state regimes of their host society.

Keywords: Multi-lingua francas, linguistic regimes, migration, 'ethnic' call shops, Catalonia

*Corresponding author: Maria Sabaté Dalmau, Universitat de Lleida - English and Linguistics Department, Plaça Víctor Siurana 1 Despatx 2.20, bústia L5, 25003 Lleida, Catalonia, Spain, E-mail: maria.sabate@dal.udl.cat 


\section{Introduction}

Figure 1 is a hand-written notice that was photographed in an 'ethnic' call shop run by a Pakistani worker in a very marginal neighborhood near Barcelona City, in Catalonia, a Catalan- and Spanish-speaking bilingual region with its own quasiautonomous government, in Spain (Generalitat de Catalunya 2006). ${ }^{2}$ On a daily basis, this small business welcomed between 61 and 156 migrant customers who were mostly non-schooled and unemployed, and who lived under extremely precarious socioeconomic conditions. They all organized their life trajectories in that particular shop because it was the only informal venture which allowed them to gain access to the resources for survival which they would otherwise not be able to attain, due to their citizenship statuses as undocumented or as temporary foreign residents. That is, it was a unique local business that had become an empowering alternative shelter institution of "late capitalism" (Heller and Duchêne 2012: 3) which provided 'illegal' migrants with job opportunities, free legal advice concerning legalization issues, cheaper information and communication technology, housing, and the like, off the radar from governmental authorities.

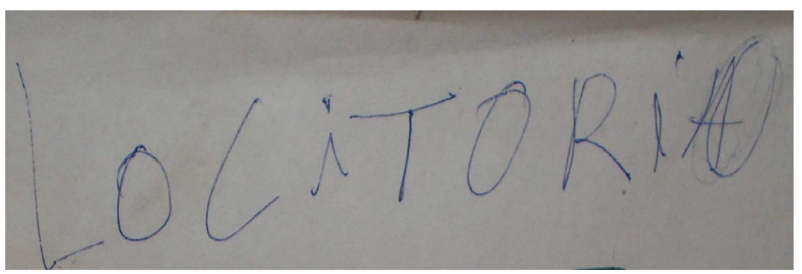

Figure 1: Notice reading locitoriao ('Call shop'). Call shop in the metropolitan area of Barcelona. October 2008. Picture taken by author.

1 The term 'ethnic' is here used as a descriptive category which makes reference to the small businesses that target transnational populations in Catalonia (including Pakistani call shops, Moroccan halal shops, Pakistani or Chinese groceries, 'Latino' hairdressers and the like). It is presented in inverted commas to denote reservations with ethnocentric perspectives which use this term as a social category and, consequently, emphasize the ethnocultural (cum racial) 'differences' or 'exceptionalities' of these migrant-regulated ventures.

2 In Catalonia, the Spanish and the Catalan languages coexist in a complex manner. Catalan, which has a long historical trajectory of prosecution and subordination, and which is not recognized as an official language by the European Union, is regarded as the co-official minority national language or llengua pròpia ('vernacular code') of Catalonia, whereas Spanish has a secured status quo both as the dominant official majority language of the entire Spanish nation-state, and as a pioneering global lingua franca, too. (The Catalan sociolinguistic context is summarized in Pujolar and Gonzàlez 2013; Woolard 2013; Woolard and Frekko 2013.) 
The lower- and uppercase letters of the notice in Figure 1 may roughly be typed as locitoriao. This stands for 'call shop' in an amalgamation of allochtonous and autochthonous linguistic codes transcending 'neat' language boundaries which exemplifies the sorts of "multi-lingua francas" (Makoni and Pennycook 2012: 449) that have colonized the discursive spaces of many urban areas in globalized cities like Madrid or Barcelona (Martín-Rojo 2012: 289-290).

Despite being heteroglossic in nature, the word locitoriao in Figure 1 is ideologically framed within a Spanish monolingual floor. When asked, migrant call shop users systematically made sense of this term as having been written in what they called castellano ('Castilian') and/or español ('Spanish'). Having strong political connotations, ${ }^{3}$ these two naming practices only make sense within a common regime of thought which links a given linguistic code to a homogeneous population inhabiting a uniformly depicted geography (see, e.g., Gal 2006; Heller 2007). In this case, the terms 'Castilian' and 'Spanish' are indexical of a prevalent linguistic code which is presented as the dominant or the nation-state language 'belonging' to the Spanish peninsular and to the postcolonial Latin American territories, essentialized as a post-national "Spanishspeaking condominium” (García Delgado et al. 2007: 21).

Call shop users also fostered the regimentation of this particular discursive space in standard Spanish norms in actual communicative practices. In the written mode, this can be observed in the last two overlapping letters of the word locitoriao (in Figure 1). A migrant call shop user with a knowledge of the morphemic gender in Standard Peninsular Spanish tried to 'correct' the feminine - $a$ ending and to substitute it for the - $o$ ending, getting closer to the orthodox spelling for this masculine noun: locutorio ('call shop'). This illustrates how transnational populations paradoxically sanction their linguistic hybridity (particularly their non-normative orthographic practices) and discipline themselves in pervasive ways of doing literacy, in uncharted multi-lingua franca spaces regulated by their users in a bottom-up manner; in connection to, but at the margins of, the established "linguistic regimes" (Kroskrity 2000: 3) of their host society. In other words, Figure 1 reveals how heterogeneous migrant groups both publicize and simultaneously censure their non-official "linguistic way of (inter)

3 The term 'Castilian' frequently makes reference to the particular region of the Iberian Peninsula where this language comes from, Castilla (DRAE 2014). It seemingly acknowledges a diversity of other linguistic codes (like Catalan) but disregards others (like Portuguese), in this geographical area. In Catalonia, the term 'Spanish' is variously used both in the peninsular and in the global spheres, sometimes to criticize its imposition on the part of a linguistically exclusionary Spanish nation-state (which silences languages such as Catalan), and sometimes to justify and to legitimize its dominion as a high-status 'uniting' global lingua franca (Del Valle 2006). 
acting" (Thurlow and Mroczek 2011: xxx), in this case in the written mode, in global "translinguistic Spanish" (Corona et al. 2013: 186). Thus, the term locitoriao epitomizes the types of fully-fledged, ecumenical "point zero" codes (Blommaert 2012: 92) that migrants from disparate backgrounds mobilize 'from below,' in intercultural encounters that deal with establishing and maintaining social contacts with other migrant populations that may be of crucial support when organizing transnational living.

From a critical sociolinguistic perspective of an ethnographic basis (Duchêne et al. 2013), in this article I contribute to the study of the social meanings of these marginalized populations' multi-lingua francas, here understood as practice (i.e. as multi-voiced situated social actions) and as ideology (i.e. as empirically observable variegated indexes of the norms that govern linguistic behaviors; Blommaert 1999; Heller 2007; Schieffelin et al. 1998). I first approach the migrants' non-detachable combination of multilingual capitals (in written Arabic and Spanish, for instance) as encompassing a highly flexible "we-code" (Gumperz 1982: 66) whereby transnational social actors locally protect and distribute their resources for survival solely among themselves. I also present them as a display of a fluid migrant identity, a multifaceted migrant "voice" (Jaffe and Walton 2000: 562), with which these populations subvert and appropriate the urban linguistic landscapes of their neighborhoods when seeking transnational survival, publicly vindicating "linguistic distance" (Androutsopoulos 2000: 515) from hegemonic forms of 'doing' language. I then claim that in emergent migrant-regulated spaces these complex multi-lingua franca practices and ideologies are also simultaneously (and systematically) framed within a unified monolingual floor. I show that migrants concurrently censor their grassroots translinguistic practices and 'self-correct' into peninsular and Latin American Spanish norms, exposing their deep understanding of standard versus non-standard language boundary-making processes. I argue that this is partly due to the fact that they try to display their command of the linguistic code which in Catalonia is presented to them as the de facto 'asset' (i.e. as the instrumental and sociocultural means) to attain fully-fledged citizenship rights: Spanish, the official majority language of the Spanish nation-state. ${ }^{4}$ I finally suggest that an informant-focused ethnographic lens to the particular bottom-up communicative practices which are meaningful for migrants may

\footnotetext{
4 The key institutions that manage the migrants' multilingualism through the use of the Spanish language in Catalonia include many public healthcare (Moyer 2011), schooling (Newman et al. 2013) and administration sectors (Codó 2008); volunteerism and (religiouslyinspired) social services organisations (Garrido 2013; Pujolar 2007a, 2009); and multinationals and private business companies too (Pujolar 2007b; Sabaté i Dalmau 2012).
} 
generate new knowledge concerning the in- and out-group stratifying social hierarchies that regulate present-day transnational networks in Europe, in unique spaces where these have a degree of "social agency" (Giddens 1984: 5) or power to challenge hegemonic language standardization and to establish an alternative sociolinguistic order of things. I argue that in these under-studied shelter institutions, though, migrants end up participating in the linguistic marginalization to which they are subject. I suggest that the written practices of populations living under conditions of acute precariousness display their successful transgressive colonization of the urban floor but, at the same time, reveal the ways in which the unschooled and the undocumented assert 'integration' by fostering, instead, a mono-lingua franca space for themselves. Thus, I conclude that, in their search for securing subsistence, migrant populations actively contest, but simultaneously succumb to, and re-produce, the exclusionary Spanish monolingual nation-state regimes of their host society.

The methodology that I employed for this study consisted of a two-year "network ethnography" (Howard 2002: 551) of an extremely diverse social network of 20 pauperized labor migrants, men and women, aged between 27 and 52 . Born in Pakistan, Kashmir, Morocco and Romania, and, to a lesser extent, El Salvador, the Dominican Republic, Bolivia, Guinea, Equatorial Guinea, Cuba and Brazil, these informants settled in Catalonia between 2002 and 2010, after having lived in other parts of Spain (mostly Madrid) and, in some cases, in Europe (basically, the UK and Greece), normally for short, difficult periods of time - due to legality issues, only very few could visit their place of birth on a more or less regular basis. Their transnational family configurations, which were also very heterogeneous, responded to their urgent need for protecting their individual resources for survival and their family incomes. Some had migrated alone and lived in single rooms with same-sex individuals who had also left their children or partner behind; others had planned their mobility trajectories with their extended families, and lived together in crowded sub-let apartments, with some prospects of 'return'; and still some others scraped out a living by moving from an acquaintance's place to another. They all shared the fact that they networked, on a daily basis, in an 'ethnic' call shop located in an overwhelmingly Spanish-speaking marginal neighborhood. This was situated on the periphery of a medium-sized town near Barcelona which had experienced the highest rates of employment loss and the highest crime rates, and which provided the conditions for their engagement with a very active local informal economy, during the time of the fieldwork, between 2007 and 2009 (the unemployment rate among foreigners reached 39\% for the first time in Catalonia, one of the highest percentages in Europe, in 2012; Observatori d'Empresa i Ocupació 2012: 4). 
The research space that I investigated included this business as well as the public benches on the pavement in front of it, the two bars in the nearby that the informants frequented, and their households. Having lived in the area for three years and a half, I focused on the analysis of these social actors' (1) communicative capitals and linguistic repertoires, (2) life trajectories and mobility practices, (3) (informal) work experiences, prospects and aims, and (4) in- and out-group social relationships and encounters. The data assembled for the study by means of active participant observation included open-ended informal interviews involving these 20 call shop users (gathered with voice informed consent); naturally-occurring interactions recorded among themselves; and a wide range of visual materials, which I always read and interpreted with the informants. ${ }^{5}$ For the aims of this article, I focus on a hand-written welcome note and on four room-to-let advertisements photographed in the call shop that I researched, and I analyze three interview extracts gathering self-reflexive comments concerning linguistic diversity in town, made by a Guinean, a Moroccan and a Cuban man (the full ethnographic project on which this article expands is available in Sabaté i Dalmau 2014).

\section{Migrants' linguistic resistance practices: Multi-lingua franca spaces as survival institutions challenging hegemonic language standardization processes}

Figure 2 is a room-to-let advertisement which, publicly posted on the call shop wall that I investigated, literally reads (from left to right): "I rent a room. September 4, 2008, in [name of the town], fully furnished. To a responsible woman and with work." It contained no morphosyntactic or syntactic unorthodoxies, and, carefully punctuated, it followed the orthographic conventions of Standard Peninsular Spanish. Besides, it had a clear organizational structure, with different stylized letter sizes that allowed readers to distinguish the title, the date, and the main body of the advertisement (in the removed details, a telephone

5 The protection of the participants' identities was ensured by the Ethics Committee at the Autonomous University of Barcelona (registration file $725 \mathrm{H}$ ) and by a cooperative of lawyers committed to situations of marginalization and racism called Col-lectiu Ronda. All names are pseudonyms, and the exact location of the neighborhood under study is not provided for anonymity purposes. 


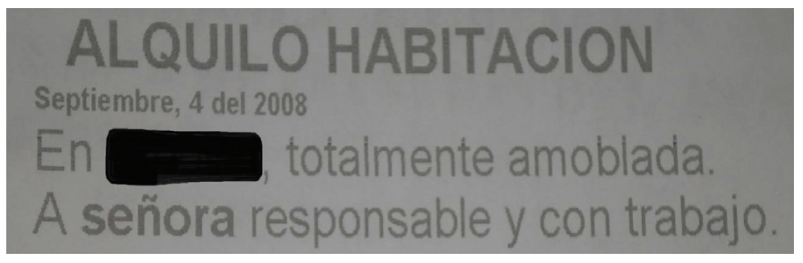

Figure 2: To-let advertisement (with selected details removed). Call shop in the metropolitan area of Barcelona. September 2008. Picture taken by author.

contact was also provided). This notice was directed to a single employed woman with a reading command of Spanish, and, therefore, it disregarded the vast majority of undocumented and/or non-literate migrant clients who visited that particular 'ethnic' call shop. During the time of the fieldwork, I realized that this sort of printed work tended to be associated with wealthier 'outsiders' (i.e. outgroup local neighbors), and that it reminded customers of the discouraging administrative procedures which, in general, generated a fear of being reported to the local governmental authorities (police raids were frequent in the area). This may be the reason why, like the other 'institutional' leaflets delivered there by the town council and by the local NGOs, the notice presented in Figure 2 was actually thrown away by the Pakistani call shop worker, Naeem, in just a few days.

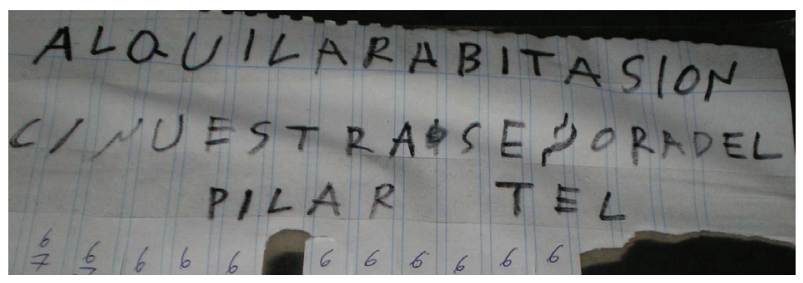

Figure 3: To-let advertisement (with selected details removed). Call shop in the metropolitan area of Barcelona. August 2008. Picture taken by author.

Figure 3 is also an ordinary to-let advertisement posted on the call shop wall, hand-written in non-standard Spanish, in capital letters. It roughly reads (from left to right): "RENTROOM STREET NUESTRAфSEÑORADEL PILAR TEL." An equivalent of this notice in many peninsular and Latin American Spanish standard forms may be: 'Alquilo habitación. C/ Nuestra Señora del Pilar. Tel.' ('I rent a room. Street Nuestra Señora del Pilar. Tel.') - telephone contact details, here removed, also ensued. It was posted by Salim, a middle-aged unemployed man of Moroccan origin who always came in and out of the call shop in a rush, 
and who spent that summer looking for a roommate with whom to share household expenses.

Salim's notice contains traces of heterography, or "the deployment of graphic symbols that defy orthographic norms” (Blommaert 2008: 7). This is seen, for example, in the absence of punctuation marks, accents, and other scriptural conventions, as well as in the word abitasion, which stands for habitación. (I photographed other non-mainstream orthographic modalities for this particular word which included habtacion, habitasion and habitacion.)

The advertisement also bears traces of "xenoglossy" (Jacquemet 2005: 273), understood as the linguistic ability to access and to appropriate a code without actually having fully mastered it, as shown, for example, in the employment of inconsistent syntactic structures like elliptical constructions and non-inflected verb forms. This is illustrated here with the use of the bare infinitive alquilar, which means 'to rent,' and with the presence of "polyvalent amalgamated spellings” (Anis 2007: 101, 104), where spaces between single words are eliminated and written together as one single 'ungrammatical' unit, as in aquilarabitasion (instead of alquilar habitación) and senoradel (instead of señora del). Salim's hesitation or uncertainty about the division of word units in Spanish may be observed in his use of a hand-written symbol (similar to ' $\phi$ ') which, when providing the street name, divides the Spanish adjective nuestra ('our') and the noun Pilar (a common female name), indicating that these two words were not meant to be written as one single unit. The notice is successful in that it manages to convey most of the metalinguistic information required by prospective household-sharers, since, even to non-schooled informants, it multimodally indicates that there is a room for rent located near the cheap supermarkets and other resourceful 'ethnic' shops (hence, unlike room-to-let advertisements printed by literate users, Salim's advertisement did not include the street number, for the area of the neighborhood was rendered more important than the exact location of the flat).

Apart from heterography and xenoglossy, the advertisement also contains orality traits which may reflect accent, as in the phonetic writing of abitasion, where the grapheme $\langle\mathrm{h}>$ is usually unpronounced, and the letter $\langle\mathrm{c}\rangle$ is articulated as a devoiced consonant sound $(/ \mathrm{s} /)$ in many Latin American standard Spanish forms. Finally, the transcodic marks that semiotically denote 'digraphia' (Sebba 2012: 4) or multiple literacies and creative amalgamations of the Roman and the Arab scripts are observable in the three letters which equate to the Spanish graphemes $<$ n $>$ (used twice) and $<\tilde{n}>$ (used once, in Figure 3). Salim's strokes for $<\mathrm{n}\rangle$ in the last letter of abitasion and in the first letter of nuestra resemble the beginning of the Arabic letter $<\omega>$ (pronounced as /s/, in Modern Standard Arabic). The grapheme for $<\tilde{n}>$ in señora ('lady') may be transliterated 
as the beginning of $\langle ت>(/ t /)$ - clients provided confirmation for this, too. Arguably, these are "graphemic manipulations" (Androutsopoulos 2000: 517) which are iconic of the aesthetic inclusion of calligraphic 'Arabicness' (though not of Arabic phonology, in this case) into the particular migrant-to-migrant communication tools with which transnational populations actively participate in, and compete for, the local flat-sharing market.

Needless to say, these sorts of practices were also recorded in the spoken mode, for transnational populations established "intercultural communication" (here understood in Piller's terms; Piller 2011: 5) among themselves with truly translinguistic routine expressions. In the call shop, some examples of these included the systematized use of the recarga (for la recarga or 'the mobile phone top-up') and of el tecnicion (for el técnico or 'the technician'), both revealing Spanish and English oral multilingual traces, in this case.

These counter-hegemonic multi-lingua francas shall be decoded (i.e. contextually framed) in the particular linguistic market in which they operate and in which they are meaningfully circulated, such as in migrant-regulated shelter institutions. The written data that I have analyzed so far are appropriations of the ways in which Catalan society at large utilizes room-to-let advertisements. In this sense, they reveal the pragmatic grassroots flexibilization or informalization of established standard norms by means of which migrant populations, drawing on a series of communicative resources that display their understandings of, and socialization in, 'native' ways of conveying information, get organized in their self-regulated networking spaces. Besides, these multi-lingua francas are also expressive cues for identity (self)-positioning, because, at least in the case of the notices that remain on the walls of 'ethnic' businesses, they indicate that the rooms advertised are available for in-group members of given migrant social networks. In this regard, they are linguistic expressions of "communicative nearness" (Androutsopoulos 2000: 520) to ethnolinguistically close compatriots who may have experienced similar socioeconomic challenges in their search for individual or transnational family security. Therefore, they index and embody the flavor of the migrants' "linguistic ways of being" (Thurlow and Mroczek 2011: xxiii), and, consequently, exclude local populations as participators in the re-distribution of resources for transnational survival.

As has been vastly reported, outside migrant-regulated discursive spaces these written notices and multilingual expressions tend to be dismissed as 'immigrantese' talk - as “non-quite-languages” (Gal 2006: 15). The former, the migrants' written repertoires, index a 'low' command of conventional graphic representations of standard codes (Preston 1985: 328) and are pejoratively regarded as a 'bad copy' of mainstream notices. The latter, the migrants' oral translinguistic capitals, tend to be conceived of as "faulty" or "defective" speech 
(Miethaner 2000: 541; see, also, Ferguson 1975). Consequently, the transnational populations who mobilize these multi-lingua franca resources are frequently infantilized and stigmatized as "deviant" users of both allochthonous and autochthonous languages (Sebba 2012: 10).

Against these stereotyping views, the migrants' creative range of communicative resources that have been described here is revealing of their conscious and unconscious linguistic resistance against the linguistic marginalization to which they are subject in Catalonia. Apart from denoting non-complicity with the established language norms, these practices also show that marginalized transnational populations have successfully self-incorporated and enculturated into their host society - even when being non-schooled. Besides, they unveil the anti-normative, subversive ways by means of which they actively vindicate a legitimate space for their ethnolinguistic identities in the public arena. Therefore, these migrants' multi-lingua francas do not only transgress the ideological foundations of the 'native speaker' (Pennycook 2007: 36) and show that Spanish is no longer monopolized or regimented by populations from Spanishspeaking backgrounds. They also crucially make "non-standard voices visible/ audible in a medium that habitually does not recognize them" (Jaffe 2000: 498) and propose, and actually publicly establish, "alternate models of the social world" (Gal 2001: 425), from the margins. In short, they demonstrate that migrants are also acting collectives with the degree of social agency to shake the boundaries of what counts as the legitimate ways of speaking, reading and writing, overtly challenging the rules of the game established, in a top-down fashion, by local governmentality institutions, and by society at large. What is more, they expose the potential that the emergent alternative institutions of late capitalism have to make linguistic diversity more and more visible, and more and more audible. This may partly explain why, since 2002, the local municipalities in the Barcelona metropolitan area have notably reduced the number of call shop licences that they grant per year and have simultaneously established a series of restrictive municipal ordinances which forbid the public display of any type of written information outside their premises, for 'ethnic' business that are already running (these ordinances are at times accompanied by door-bydoor inspections). ${ }^{6}$ This provides clear evidence that the multi-lingua franca spaces of twenty-first-century migrant networks have taken roots and have successfully started to colonize the Catalan urban floor, shaking the precepts of the current linguistic regimes that overtly target 'non-citizens'.

6 See municipal laws BOP 2002, 2005, 2006, 2008 in the Barcelona metropolitan area, by way of example. 


\section{Migrants' linguistic regimentation practices: The display of legitimate socialization and the struggle to attain fully-fledged citizenship statuses}

Despite their empowering potential, the multi-lingua franca practices in 'ethnic' businesses that have been presented in the previous section are markedly inserted into dominant sociolinguistic orders which assign superior values to mainstream standard norms (see, also, Jacquemet 2010). While it was presented as a highly multilingual space and, indeed, welcomed clients with written documents in Urdu, Arabic and English (basically with notices informally selling or exchanging products and services), the particular call shop that I investigated was in fact regimented in a unified floor, in global Spanish. All top-up and fax receipts, bank statements, invoices from telephone companies, and bills from call card distributors were provided in Standard Peninsular Spanish. Besides, the language of technology and the semantic field of numbers (the prices, hours, postal codes and opening or closing times), as well as routine expressions such as mañana ('tomorrow'), cambio ('change') or cabina ('cabin') had entered that space through translinguistic peninsular and Latin American Spanish accents, and were systematically adopted by habitual and non-habitual Spanish-speaking migrants, at the public "front-stage" (Goffman 1959: 22) ${ }^{7}$ - intimate "backstage" talk among compatriots was not frequently criticized (for example when Pakistani call shop workers gave instructions to each other in Panjabi and Urdu).

When asked, informants followed the apparently logical, but in fact highly ideologized, monolingual regime of thought which linked the Spanish nation-state with an imagined monolingually and monoculturally uniform territory ('Spain'), reproducing the homology 'one language-one nation-one population' paradigm in bilingual Catalonia, as already outlined in the introduction of this paper. This is exemplified in Extract 1, which is part of an interview taken from Sabaté i Dalmau (2014: 112-113). (The transcription conventions are provided in the Appendix. ${ }^{8}$ )

7 Competitions of linguistic capitals so as to what sort of (peninsular and/or Latin American) Spanish shall prevail in that particular call shop were scare. Normally, a combination of them was what the informants drew on, in their communicative practices. By way of example, both boli and lapicero ('pen'), ordenador and computadora ('computer') and móvil and fono ('mobile') were interchangeably employed on the desk of the 'ethnic' business, on a daily basis.

8 The interviews were conducted in the languages of the informants' own choice, although due to my non-existent or very limited knowledge of their codes (consisting of just very basic Urdu), 
Extract 1: The reproduction of Spanish monolingual ideologies.

@Location: 1 September 2008. Bar near the call shop. Barcelona metropolitan area.

@Bck: $\quad$ Aboubacar (ABO) and Abdelouahed (ABD) present their views on the sociolinguistic orders of the call shop, as well as of the neighborhood, to the researcher (RES).

01 `RES: <la gente> [?] cuando vas al locutorio <la gente qué te habla> [?]. \%tra: <people> [?] when you go to the call shop <what do people speak to you> [?].

$\rightarrow 02{ }^{\star} \mathrm{ABO}:$ me habla castellano.

\%tra: they speak to me in Castilian.

$\rightarrow 03{ }^{\star} \mathrm{ABD}: \quad+{ }^{\wedge}$ cada uno en su idioma.

\%tra: $\quad+^{\wedge}$ everyone in his own language.

$04{ }^{\star}$ RES: <cada uno en su idioma> [?] pero cuando vas a pedir o preguntas \# o aquí al bar o $+\ldots$

\%tra: <everyone in his own language> [?] but when you order or ask \# or here in the bar or $+\ldots$

\%add: To Abde.

$\rightarrow 05{ }^{\star} \mathrm{ABD}: \quad+{ }^{\wedge}$ castellano.

\%tra: $\quad+{ }^{\wedge}$ Castilian.

$\rightarrow 06{ }^{\star}$ ABO: castellano.

\%tra: Castilian.

07 ^RES: castellano?

\%tra: Castilian?

$\rightarrow 08$ *ABD: sí.

\%tra: yes.

$\rightarrow 09{ }^{\star}$ RES: <y cómo es que:> [/] <y cómo es que es eso> [?] \# y: <por qué no el catalán> [?].

\%tra: <and how come:> [/] <and why is this so> [?] \# a:nd <why not Catalan> [?].

$\rightarrow 10{ }^{\star}$ ABD: hombre que en España el castellano -, el idioma el castellano. \%tra: look in Spain Castilian -, the language the Castilian.

In Extract 1, Aboubacar, a 36-year-old Guinean whose main motivation for enduring badly paid scrapyard work was to bring his partner to Catalonia,

these choices were mostly reduced to Catalan, Spanish and English, with Spanish clearly predominating as their preferred option. 
emphasizes the overarching use of Spanish (which he called "castellano") both in the call shop (line 2) and in the neighborhood (line 6). Simultaneously, coparticipant Abdelouahed, a 31-year-old unemployed construction worker from Morocco who migrated alone, illegally, by boat, acknowledges linguistic diversity and, in an overlap (line 3), assigns one single language to each call shop client (presumably, the dominant language of each customer's place of birth). He also emphasizes the habitualized use of Spanish (again called "castellano") over any other allochthonous or autochthonous language in town (in lines 5 and 8), and over the co-official minority national language of their host society, Catalan, which he presents as being almost absent in these discursive spaces (in lines 9 and 10). Finally, Abdelouahed states that, from his point of view, the language to be employed in what he actually calls “España” ('Spain') is Spanish (in line 10), apparently following available pro-Spanish ethnolinguistic (i.e. Spanish nationalist) discourses in town and, more generally, in Catalonia.

Latin American informants mobilized similar Spanish-only monolingual ideologies, perhaps with more emphasis. James, a middle-aged Cuban writer and protest poet who arrived in Catalonia in 2008 and who understood Catalan perfectly, for instance, highlighted the power of the 'Spanish-speaking nations' and legitimized the worldwide use of Spanish as an international language for both economic prosperity and for successful intercultural communication, as shown in Extract 2 (taken from Sabaté i Dalmau 2014: 118-120).

Extract 2: The defense of the dominion of global Spanish in Catalonia and worldwide.

@Location: 3 August 2008. Call shop. Barcelona metropolitan area.

@Bck: $\quad$ While seemingly acknowledging linguistic diversity, James (JAM) defends the hegemonic power of Spanish in Catalonia, in Spain and worldwide, in an interview with the researcher (RES).

$\rightarrow 01$ *JAM: pues un lenguaje común del uso de: muchos millones de personas en el mundo que es una riqueza que tiene España como es el castellano -, pues resulta relevante: \# es una divisa que tiene esta nación.

\%tra: well a common language of use o:f many millions of people in the world which is a wealth of Spain as much as Castilian is -, well it turns out to be importa:nt \# it is a currency that this nation possesses.

$[\ldots]$

$\rightarrow 02{ }^{\star}$ JAM: y se estima que en en medio siglo o un siglo ya va a ser el idioma más hablado del mundo. 
\%tra: and it is estimated that in in half a century or in a century it'll be the most widely spoken language in the world already.

$[\ldots]$

$\rightarrow 03{ }^{\star}$ JAM: mira nosotros nos estamos comunicando perfectamente.

\%tra: look we are now communicating perfectly.

$04 \star$ RES: claro.

\%tra: sure.

[...]

$\rightarrow 05$ *JAM: ahora lo que es una verdad ineludible es esto del castellano imponiéndose en el mundo y que es una riqueza que hay que cuidar y <es un> [//] es una delicia española y de España porque mal que le pese a quien le pese <esto es España $>$ [!].

\%tra: now but what is an unavoidable truth is that Castilian is growing in strength around the world and that it's a wealth that should be taken care of and <it's a> [//] it's a Spanish delight and of Spain because whether we like it or not <this is Spain $>$ [!].

In Extract 2, James presents the Spanish language as a symbol of post-national global unity and "democratic harmony" (Del Valle 2006: 32), both as a cultural (or heritage) 'richness' and as a profitable economic 'currency' of (and for) Spain (lines 1 and 5), simultaneously employing ethnic and cultural connotations liked to identity issues and 'economicist' discourses concerning the 'added value' of this code in the local and the global marketplace (see Heller \& Duchêne 2012; Kelly-Holmes 2010 for an analysis of these sort of late capitalist discourses). By trying to justify its dominion as one of the most widely spoken languages worldwide (line 2), he ends up defining it, very emotionally, as the language of a homogeneous country ('Spain'; line 5), leaving the differences between peninsular Spanishes and other Spanishes from Latin America unmentioned, and defending its mono-lingua franca status (again, both at the local and at the global levels) as crucial for serving the needs of intercultural communication (for example between habitual Catalan users like the researcher and Spanishdominant speakers like him).

These Spanish-only regimes of thought were also observed in the informants' self-regimentation practices in actual naturally-occurring interactions, as some of them (particularly those from a Spanish-speaking background) spontaneously censored the 'intrusion' of other languages into their own and into the others' routine expressions voiced in translinguistic Spanish, in the call shop under study. By way of example, the Panjabi-dominant Pakistani worker, Naeem, was every now and then harassed by young Latin American users who 
publicly complained about his 'bad' Spanish, when they did not agree with the rules of the 'ethnic' business (for example, when they had to change telephone booths due to connection problems). I observed one of them shouting ' iHabla como un hombre, coño!' ('Speak like a man, damn!') to him, for he argued that he could not understand the word cuatro ('four') when Naeem asked him to move to computer number four. When I asked the worker about that particular encounter, he explained that clients tended to disapprove of his spoken Spanish - he stated: “¿Lo ves? No les gusta!” ('See? They don’t like it!’). Naeem’s (self)“decapitalization” (Martín-Rojo 2013: 120) or delegitimation of his own linguistic resources got to a point that he sometimes claimed that he did not speak Spanish at all, while conducting his call shop tasks, daily, in this language! I also realized that some migrants from South Asia even 'Spanish-ized' their names when introducing themselves to other Spanish-speaking migrants and to the local populations of Spanish descent living in the neighborhood. Sheema, a 31-year-old Pakistani who had migrated with his wife and his two children, and who worked in a 'Latino' bar without a contract, for instance, called himself Chema (/'tfema/). In like fashion, Shabbir, a 41-year-old construction worker whose wife back in Kashmir was an English teacher who wanted to escape sociopolitical conflict by settling in Barcelona in the near future, asked his friends to call him Xavi (/'tfabi/), a Catalan male name used by Spanish- and Catalan-speaking local populations.

Concerning their written multilingual practices, I found that informants fostered the use of the dominant standard norms in this language in a similar manner. They explicitly ridiculed the translinguistic nature of their Spanishes, in particular their own and the others' scriptural practices in multimodal communication, which they also conceptualized as being 'poor' or 'faulty'. For example, they criticized the mobile phone text messages in this language that contained the sorts of multilingual traces which have been described in Section 2, and frequently asked me (the 'schooled' researcher) for 'correction' before sending them to Spanish-dominant friends and acquaintances. Therefore, they promoted the use of a single mono-lingua franca which roughly followed the established linguistic regimes and standardization orthodoxies of their host society, generally conceived of as the best way to prove attainment of what is considered "proper reterritorialization' in town, and to display legitimate linguistic socialization in it.

The migrants' discrediting and sanctioning of their own written translinguistic repertoires is illustrated in more detail in Figure 4, which is a second room-tolet advertisement which Salim posted when he saw that his previous notice (presented in Figure 3) had not been successful in attracting new roommates.

Salim's new advertisement, also hand-written, has two innovations with regard to his first trial (Figure 3). It no longer contains truncations, and the aesthetic Arabic 




Figure 4: To-let advertisement (with selected details removed). Call shop in the metropolitan area of Barcelona. July 2008 (Sabaté i Dalmau 2014: 147).

graphemes concerning the letters $<\mathrm{n}>$ and $<\tilde{\mathrm{n}}>$ have disappeared, so that his script choices no longer stylistically convey a sense of 'Arabicness'. I read these scriptural modifications as one of Salim's ways of expanding his flat-sharing offer not only to the Arabic-inferring (or Arabic-reading) community but also, perhaps, to other migrant social networks, signaling a broader migrant audience, by getting closer to the hegemonic orthographic conventions of Standard Spanish. These claims are further supported by Salim's third trial, which is yet another advertisement for the same room, presented in Figure 5.

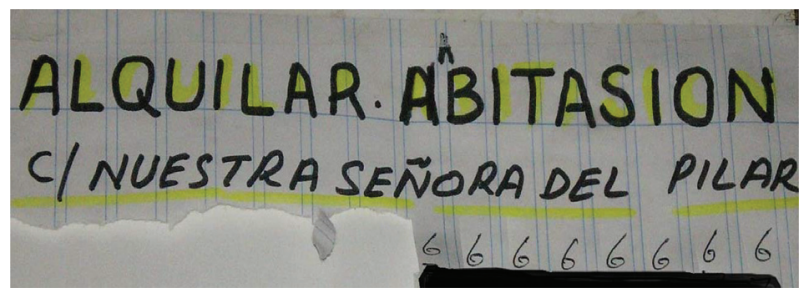

Figure 5: To-let advertisement (with selected details removed). Call shop in the metropolitan area of Barcelona. August 2008 (Sabaté i Dalmau 2014: 147).

With respect to his second notice (Figure 4), Salim's last to-let advertisement (Figure 5) has undergone a "transposition" (Blommaert and Rampton 2011: 10). That is, it has been embellished through the elongation of each individual letter, and it now follows most of the canons of mainstream Spanish orthography. The letters have also been prominently highlighted with a yellow marker in order to give them visibility on the wall of the 'ethnic' call shop. Besides, the word 'room' has been slightly modified to meet the dominant normativity rules, so that the first letter $<\mathrm{a}>$ in the second word of Figure 5 has become an unpronounced $<\mathrm{h}>$, and a small vowel $<\mathrm{a}>$ has been manually inserted on top right after it, resulting into a "respelling" (Tagg 2012: 4) which, reading habitasion, better represents the accepted form of the word 'room' (habitación). 
This reveals the non-habitual Spanish users' efforts to meet the standards of the dominant linguistic practices with which they try to compete, on equal grounds, with those migrants who are already enculturated into the monolingua franca regimes of normalcy and standardness that govern the call shop and the neighborhood, particularly with Latin American populations. (Latin American clients were advantaged in that they were fluent speakers of many Spanish varieties, though most of them were actually non-literate and nonnumerate, too.) Thus, this self-disciplining actually signals these migrants' explicit attempts to display their willingness to 'integrate'; that is, to expose their command of the linguistic correctness that prevails in town, which is mutually constitutive of the broader sociolinguistic orders governing the linguistic hierarchies of marginalized Catalan urban areas, as detailed below.

The call shop under study was located in a peripheral working-class town that was considered to be a Spanish-speaking 'language pocket' (at times this was presented in a pejorative manner, as an 'intrinsic' characteristic of this 'ethnic enclave'). The majority nation-state language, Spanish, figured highly over the minority national language of Catalonia, Catalan, whose presence was notably scarce (as attested by Woolard 2003), despite the Catalan government's efforts to 'normalize' its use in the area in all spheres of social life, after its prohibition and prosecution during the Francoist dictatorship (1939-1975). This sociolinguistic reality, which contrasted with the gradual de-politicization (and de-ethnicization) of language choice and of systematized Catalan-Spanish bilingual practices in Catalonia as a whole (Woolard and Frekko 2013), may partly be explained by its singular demolinguistic configuration, where the critical mass of habitual Catalan local users which has proved to be necessary for migrants to invest in this language (Pujolar et al. 2010: 16) was absent. About 33.69\% of its registered inhabitants were not born in Catalonia: $12.09 \%$ were documented foreign residents, and $21.60 \%$ were Spanish-speaking people who came from other regions of Spain during the 1950s and the 1960s (Idescat 2010), when approximately 1.5 million Spanish nationals (initially Spanish monolingual speakers) moved to Catalonia, in search of prosperity, during the post-Civil War economy. The analysis of the linguistic trajectories of their children (now adults or young adults), born and schooled in town, reveals that they similarly fostered the use of Spanish over Catalan, too (Fabà Prats 2012; Torres-Pla 2012; Torrijos 2013), and that they seemed to share the belief that their foreign neighbor's 'integration' shall be conducted in and through Spanish, too, following the idea that insertion into the immediate (blue-collar) marketplace in the peripheries of Barcelona, as well as into their public discursive spaces, was to be conducted in Spanish (Sabaté i Dalmau; in Press). An example of the circulation of this 'integration through Spanish' ideology was provided by Jenny, a 35-year-old 
unemployed single mother of Spanish descent, who kept teasing Naeem for not having made Spanish his habitual 'internal' language at work - once she warned him and his workmate to stop using Urdu and Panjabi among themselves, at the call shop: "Hablar en español, que estamos en España" ('Speak in Spanish, we are in Spain').

In this context, most migrant populations in the area, as elsewhere in Catalonia (Pujolar 2010: 231), chose to learn Spanish first. Against common thought, though, the informants who participated in this study understood Catalan. They knew about the sociopolitical connotations that both local languages carry (detailed in Footnotes 2 and 3), and they were aware of the fact that a command not only of Spanish but also of Catalan was required for attaining some upward socioeconomic mobility and for gaining access to important social networks and contacts in Catalonia (Pujolar 2007b). A few who had established ties with Catalan-dominant locals (mainly with construction workers, driving instructors, and bar owners, downtown) decided to invest in Catalan-Spanish bilingualism. And yet, the vast majority of them did not conceive of Catalan as belonging to their own linguistic repertoires, and followed the local integration through Spanish' ideology in which their neighbors genuinely believed (I suggest that Extract 1, with Abou's and Adbe's comments, provides further evidence of this).

This Spanish-only linguistic behavior was further complexified in the case of Latin American informants like James (see Extract 2), who were in the unique condition to claim that 'their' language was also official in Catalonia, and who perceived the non-recognition of their former social standing (and credentials) as a difficult step back which they partly expressed by not speaking Catalan (in public) and by rejecting what they perceived as institutional policies enforcing the use of Catalan-first norms, in Catalonia (Alarcón and Garzón 2011: 134; Corona et al. 2013: 183). ${ }^{9}$

These are the circumstances which explain the informants' investment in the Spanish monolingual practices and ideologies that have been described in this section, which also account for their struggle for commanding it in a 'native'-like manner, in orthodox forms, to the detriment of their translinguistic capitals and repertoires. The migrants' conscious and unconscious subjection to linguistic dispossession, therefore, responds to the fact that they understood

9 The Latin American migrants' non-choice of Catalan may also speak not of a mere dismissal of this language, but of a complex way to keep their particular Spanishes alive and to maintain their cultural distinction by sticking to them so as to publicly reject assimilation to peninsular Spanish, which is what they seem to perceive as a real threat (Marshall 2006: 521). 
that, when trying to secure subsistence, they were better positioned if they displayed their adoption of Spanish as the legitimate 'language for relocation'. For this reason, I argue that these transnational populations' linguistic regimentation practices speak of their efforts to publicly expose their successful selfincorporation, and autonomous insertion, into their host-society neighborhoods. I claim that these linguistic behaviors, at the same time, also shed light on the language-based governmentality practices which more generally modulate the migrants' access to fully-fledged citizenship statuses and citizenship rights and resources, which I understand to be mutually constitutive of the broader hegemonic monolingual sociolinguistic orders that, in and beyond marginalized discursive spaces, regulate the intricate sociolinguistic configurations of bilingual societies like Catalonia.

\section{Conclusions: The re-production of exclusionary monolingual nation-state regimes in the emerging multi-lingua franca spaces of late capitalism}

In this article, I have argued for a user-centered approach to the linguistic diversity with which undocumented migrant populations incorporate themselves into their host societies. I have tried to bridge a gap in the literature concerning the social meanings of these transnational populations' linguistic practices and ideologies by focusing on off-the-radar multi-lingua franca spaces that still remain under-explored within the field of the sociolinguistics of globalization. I have suggested that a critical ethnographic lens on these emergent shelter institutions may shed new light on the actual communicative behaviors with which these non-schooled social groups make sense of, and apprehend, their life and work trajectories from their situated positioning as the marginalized, against the backdrop of indisputably monolingual linguistic regimes of current nation-states aimed at targeting 'illegal' border crossers.

I have shown that the linguistic features which get inscribed in these nonliterate populations' ways of speaking and writing are revealing of the "resemiotization” processes (Martín-Rojo 2012: 285) that the linguistic landscapes of global cities like Barcelona are undergoing. On the one hand, I have approached the migrants' establishment and mobilization of counter-hegemonic fluid lingua francas as acts of linguistic resistance through which they appropriate, manipulate and colonize the urban floor; in this case, in anti-normative, translinguistic 
Spanish. I have claimed that these silenced multi-lingua francas have become, as well, part and parcel of the subversive acts of identity whereby migrants publicly display their "symbol of commitment" (Androutsopoulos 2007: 349) to other pauperized social networks and secure transnational survival among themselves, in an intra-group manner. That is, I have posited that they have become a collective means to attain the degree of social agency necessary to autonomously access (and to protect) vital resources, which proves that transnational populations actively contest and challenge the sociolinguistic hierarchies established by society at large.

On the other hand, I have reported on the migrants' simultaneous submission to, and self-disciplining in, dominant language standardization processes; in this case in peninsular and Latin American Spanish norms. I have focused on their systematized and ad hoc self-corrections both in oral and written modes of communicating, with a particular emphasis on the ways in which they make every effort to follow legitimate orthodox scriptural conventions which are indexical of fully-fledged citizenship statuses, and, therefore, of citizenship rights. I have also suggested that they have a deep understanding of, and strategize with, both the local and global ethnolinguistic connotations and the 'economicist' conceptions of language that regulate the sociolinguistic order of things in which they are now fully immersed.

I have tried to take a step further by approaching these nuanced constellations of allochthonous and autochthonous repertoires and these ambivalent linguistic ideologies through the lens of the silent reproduction of social difference and social inequality on the part of a group of social actors who end up participating in their own social categorization as the "language-less" of late capitalism (Blommaert et al. 2005: 213). I have argued that linguistic resistance is not solely indexical of the migrants' conscious and unconscious non-complicity to prevalent language-mediated governmentality norms, and I have posited that linguistic regimentation is not simply a sign of acceptance of one's linguistic decapitalization. Instead, I have fostered an understanding of the migrants' linguistic resistance and regimentation practices as intricate manifestations of the ways in which they strive through enforced 'symbolic domination', a "form of complicity [to the official language] which is neither passive submission to external constraint nor a free adherence to [its] values" (Bourdieu 1991: 50-51). I have thus argued that this symbolic domination exposes, and gets to the roots of, not only the structural (top-down) exclusionary practices that get imposed upon migrant populations vindicating linguistic socialization in their hostsociety neighborhoods, but also of the nuanced ways in which these may also be paradoxically taken up (and legitimized) in a bottom-up manner, among migrants themselves. 
Finally, I have reached the conclusion that the emergent multi-lingua franca spaces of the twenty-first-century allow for the investigation of how extremely diverse populations contest and challenge but, in fact, re-produce, the censoring of their myriad communicative capitals and literacy repertoires for the sake of individual security and transnational family subsistence, in uncharted shelter institutions that hide the alphabets of the future which today emanate from the forgotten peripheral sociolinguistic realms of complex bilingual European societies in late capitalism.

Acknowledgment: I am very grateful to the informants who agreed to participate in this study, and I also want to thank Safae Jabri for her help with some clarifications concerning Modern Standard Arabic. Any shortcomings are, of course, mine.

Funding: This research was funded by the following research grants: FFI201126964 (MINECO; Spanish Government), conferred to the UAB-based research group CIEN (Intercultural Communication and Negotiation Strategies), and 2014 SGR 1061 (AGAUR; Catalan Government), granted to the UdL-based group CLA (Circle of Applied Linguistics).

\section{Appendix: Transcription system}

\section{Dependent tiers:}

@Location: provides the date and the geographical location of interviews @Bck: provides background information concerning the topic and the participants \%tra: $\quad$ provides a free translation of turns in languages other than English

\section{Transcription conventions:}

$\begin{array}{ll}+^{\wedge} & \text { quick uptake or latching } \\ +\ldots & \text { trailing off } \\ \# & \text { pause } \\ {[\ldots]} & \text { omitted exchange } \\ \langle> & \text { scope } \\ {[!]} & \text { stressing } \\ : & \text { lengthened vowel } \\ {[/]} & \text { repetition } \\ {[/ /]} & \text { retracing, reformulation }\end{array}$


? end-of-turn rising contour

! end-of-turn exclamation contour

-, intra-turn fall-rise contour

\section{References}

Alarcón, Amado \& Luís Garzón. 2011. Evaluation of social mobility and language in context. In A. Alarcón \& L. Garzón (eds.), Language, migration and social mobility in Catalonia, 123-138. Leiden \& Boston, MA: Brill.

Androutsopoulos, Jannis K. 2000. Non-standard spellings in media texts: The case of German fanzines. Journal of Sociolinguistics 4(4). 514-533.

Androutsopoulos, Jannis. 2007. Language choice and code switching in German-based diasporic web forums. In B. Danet \& S.C. Herring (eds.), The multilingual Internet: Language, culture, and communication online, 340-361. Oxford: Oxford University Press.

Anis, Jacques. 2007. Neography: Unconventional spelling in French SMS text messages. In B. Danet \& S.C. Herring (eds.), The Multilingual internet. Language, culture, and communication online, 87-115. Oxford: Oxford University Press.

Blommaert, Jan (ed.). 1999. Language ideological debates. Berlin: Mouton de Gruyter.

Blommaert, Jan. 2008. Grassroots literacy. Writing, identity and voice in central Africa. London \& New York: Routledge.

Blommaert, Jan. 2012. Chronicles of complexity: Ethnography, superdiversity, and linguistic landscapes. Tilburg Papers in Cultural Studies 29. http://www.tilburguniversity.edu/ upload/19fb666f-300e-499b-badf-90204b0e89b1_tpcs\%20paper29.pdf (accessed 2 May 2014).

Blommaert, Jan, James Collins \& Stef Slembrouck. 2005. Spaces of multilingualism. Language \& Communication 25(3). 197-216.

Blommaert, Jan \& Ben Rampton. 2011. Language and superdiversity: A position paper. Working Papers on Urban Language and Literacies 70. http://www.kcl.ac.uk/sspp/departments/ education/research/ldc/publications/workingpapers/the-papers/70.pdf (accessed 26 June 2015).

BOP. 2002. Terrassa. Aprovació definitiva de l'ordenança reguladora dels establiments de serveis telefònics per a ús públic, 45-46. Number 128, 29 May. Barcelona: Diputació de Barcelona.

BOP. 2005. Rubí. Aprovació definitiva de l'ordenança reguladora dels establiments de serveis telefònics per a ús públic, 52-53. Number 136, 9 July. Barcelona: Diputació de Barcelona.

BOP. 2006. Montcada i Reixac. Aprovació definitiva de l'ordenança municipal reguladora dels locutoris telefònics, 21-23. Number 217, 11 September. Barcelona: Diputació de Barcelona.

BOP. 2008. Ripollet. Projecte d'establiment i reglament per a l'establiment de funcionament del servei públic municipal de telecentre, 119-120. Number 287 (3), 29 November. Barcelona: Diputació de Barcelona.

Bourdieu, Pierre. 1991. Language and symbolic power. Cambridge, MA: Harvard University Press. 
Codó, Eva. 2008. Immigration and bureaucratic control: Language practices in the public administration. Berlin \& New York: Mouton de Gruyter.

Corona, Víctor, Lucila Nussbaum \& Virginia Unamuno. 2013. The emergence of new linguistic repertoires among Barcelona's youth of Latin American origin. International Journal of Bilingual Education and Bilingualism 16(2). 182-194.

Del Valle, José. 2006. US Latinos, la hispanofonía, and the language ideologies of high modernity. In C. Mar-Molinero \& M. Stewart (eds.), Globalization and language in the Spanish-speaking world: Macro and micro perspectives, 27-46. Houndmills: Palgrave Macmillan.

DRAE. 2014. Castellano. http://lema.rae.es/drae/?val=castellano (accessed 2 May 2014).

Duchêne, Alexandre, Melissa G. Moyer \& Celia Roberts. 2013. Introduction: Recasting Institutions and work in multilingual and transnational spaces. In A. Duchêne, M. G. Moyer \& C. Roberts (eds.), Language, Migration and Social Inequalities. A Critical Sociolinguistic Perspective on Institutions and Work, 1-21. Bristol: Multilingual Matters.

Fabà Prats, Albert. 2012. L'evolució dels usos professionals a Catalunya del 1997 al 2008. Treballs de Sociolingüística Catalana 22. 41-58.

Ferguson, Charles A. 1975. Toward a characterization of English Foreigner talk. Anthropological Linguistics 17(1). 1-14.

Gal, Susan. 2001. Language, gender, and power: An anthropological review. In A. Duranti (ed.), Linguistic anthropology: A reader, 420-430. Malden, MA \& Oxford: Blackwell.

Gal, Susan. 2006. Migration, minorities and multilingualism: Language ideologies in Europe. In C. Mar-Molinero \& P. Stevenson (eds.), Language ideologies, policies and practices. Language and the future of Europe, 13-27. Basingstoke \& New York: Palgrave Macmillan.

García Delgado, José Luís, José Antonio Alonso \& Juan Carlos Jiménez. 2007. Economía del Español. Una introducción. Madrid: Ariel.

Garrido, Maria Rosa. 2013. La gestió del multilingüisme en els serveis d'acollida de les ONG: un estudi de cas. In F.X. Vila \& E. Salvat (eds.), Noves immigracions i llengües, 97-118. Barcelona: MRR.

Generalitat de Catalunya. 2006. Estatut d'Autonomia de Catalunya. Barcelona: BIGSA Indústria Gràfica.

Giddens, Anthony. 1984. The constitution of society. Outline of the theory of structuration. Cambridge: Polity Press.

Goffman, Erving. 1959. The Presentation of Self in Everyday Life. Garden City, New York: Doubleday.

Gumperz, John J. 1982. Discourse Strategies. Cambridge: Cambridge University Press.

Heller, Monica. 2007. Bilingualism as ideology and practice. In M. Heller (ed.), Bilingualism: A social approach, 1-22. London: Palgrave Macmillan.

Heller, Monica \& Alexandre Duchêne. 2012. Pride and profit: Changing discourses of language, capital and nation-state. In A. Duchêne \& M. Heller (eds.), Language in late capitalism: Pride and profit, 1-21. New York: Routledge.

Howard, Philip N. 2002. Network ethnography and the hypermedia organization: New media, new organizations, new methods. New Media \& Society 4(4). 550-574.

Idescat. 2010. Vallès Occidental, població per lloc de naixement. Institut d’Estadística de Catalunya. http://www.idescat.cat/pub/?id=aec\&n=257\&t=2011\&x (accessed 13 July 2014).

Jacquemet, Marco. 2005. Transidiomatic practices: Language and power in the age of globalization. Language \& Communication 25(3). 257-277. 
Jacquemet, Marco. 2010. Language and transnational spaces. In P. Auer \& J. E. Schmidt (eds.), Language and space: An international handbook of linguistic variation, 50-69. New York: Mouton de Gruyter.

Jaffe, Alexandra. 2000. Introduction: Non-standard orthography and non-standard speech. Journal of Sociolinguistics 4(4). 497-513.

Jaffe, Alexandra \& Shana Walton. 2000. The voices people read: Orthography and the representation of non-standard speech. Journal of Sociolinguistics 4(4). 561-587.

Kelly-Holmes, Helen. 2010. Markets and languages: Sociolinguistic perspectives. In H. KellyHolmes \& G. Mautner (eds.), Language and the market, 20-29. London: Palgrave Macmillan.

Kroskrity, Paul V. 2000. Regimenting languages: Language ideological perspectives. In P. V. Kroskrity (ed.), Regimes of language. Ideologies, polities, and identities, 1-34. Santa Fe, New Mexico \& Oxford: School of American Research Press and James Currey.

Makoni, Sinfree \& Alastair Pennycook. 2012. Disinventing multilingualism: From monological multilingualism to multilingual franca. In M. Martin-Jones, A. Blackledge \& A. Creese (eds.), The Routledge handbook of multilingualism, 439-453. Abingdon: Routledge.

Marshall, Steve. 2006. Spanish-speaking Latin Americans in Catalonia: Reflexivity and knowledgeability in constructions of Catalan. In C. Mar-Molinero \& M. Stewart (eds.), Globalization and language in the Spanish-speaking world: Macro and micro perspectives, 158-177. Houndmills: Palgrave MacMillan.

Martín-Rojo, Luisa. 2012. Paisajes lingüísticos de indignación. Prácticas comunicativas para tomar las plazas. Anuari del Conflicte Social 2012. 275-302.

Martín-Rojo, Luisa. 2013. (De)capitalizing students through linguistic practices. A comparative analysis of new educational programmes in a global era. In A. Duchêne, M.G. Moyer \& C. Roberts (eds.), Language, migration and social inequalities. A critical sociolinguistic perspective on institutions and work, 118-146. Bristol: Multilingual Matters.

Miethaner, Ulrich. 2000. Orthographic transcriptions of non-standard varieties: The case of earlier African-American English. Journal of Sociolinguistics 4(4). 534-560.

Moyer, Melissa G. 2011. What multilingualism? Agency and the unintended consequences of multilingual practices in a Barcelona health clinic. Journal of Pragmatics 43(5). 1209-1221.

Newman, Michael, Adriana Patiño-Santos \& Mireia Trench-Parera. 2013. Linguistic reception of Latin American students in Catalonia and their responses to educational language policies. International Journal of Bilingual Education and Bilingualism 16(2). 195-209.

Observatori d’Empresa i Ocupació. 2012. Butlletí de Població Estrangera i Mercat de Treball. Generalitat de Catalunya, Departament d'Empresa i Ocupació.

Pennycook, Alastair. 2007. Global Englishes and transcultural flows. London \& New York: Routledge.

Piller, Ingrid. 2011. Intercultural communication: A critical introduction. Edinburgh: Edinburgh University Press.

Preston, Dennis R. 1985. Mowr and mowr bayud spellin': Confessions of a sociolinguist. Journal of Sociolinguistics 4(4). 614-621.

Pujolar, Joan. 2007a. African women in Catalan language courses: struggles over class, gender and ethnicity in advanced liberalism. In B.S. McElhinny (ed.), Words, worlds and material girls: Language, gender and globalization, 305-348. Berlin \& New York: Mouton de Gruyter. 
Pujolar, Joan. 2007b. The future of Catalan: Language endangerment and nationalist discourses in Catalonia. In A. Duchêne \& M. Heller (eds.), Discourses of endangerment: Interest and ideology in the defence of language, 121-148. London: Continuum.

Pujolar, Joan. 2009. Immigrants in Catalonia: Marking territory through language. In J. Collins, S. Slembrouck \& M. Baynham (eds.), Globalization and language in contact: Scale, migration, and communicative practices, 85-105. London \& New York: Continuum.

Pujolar, Joan. 2010. Immigration and language education in Catalonia: Between national and social agendas. Linguistics and Education 21. 229-243.

Pujolar, Joan \& Isaac Gonzàlez. 2013. Linguistic 'mudes' and the de-ethnicization of language choice in Catalonia. International Journal of Bilingual Education and Bilingualism 16(2). 138-152.

Pujolar, Joan, Isaac Gonzàlez, Anna Font \& Roger Martínez. 2010. Llengua i joves: Usos $i$ percepcions lingüístics de la joventut catalana. Col.lecció aportacions 43. Barcelona: Generalitat de Barcelona.

Sabaté i Dalmau, Maria. 2012. 'The official language of Telefónica is English': Problematising the construction of English as a lingua franca in the Spanish telecommunications sector. Atlantis 34(1). 133-151.

Sabaté i Dalmau, Maria. 2014. Migrant communication enterprises: Regimentation and resistance. Bristol: Multilingual Matters.

Sabaté i Dalmau, Maria. In Press. El català dels locutoris: pràctiques i ideologies lingüístiques de la migració en espais urbans castellanoparlants. Treballs de Sociolingüística Catalana 26.

Schieffelin, Bambi B., Kathryn Woolard \& Paul V. Kroskrity (eds.). 1998. Language ideologies: Practice and theory. Oxford \& New York: Oxford University Press.

Sebba, Mark. 2012. Orthography as social action: Scripts, spelling, identity and power. In A. Jaffe, J. Androutsopoulos \& M. Sebba (eds.), Orthography as social action. Scripts, spelling, identity and power, 1-20. Boston \& Berlin: Mouton de Gruyter.

Tagg, Caroline. 2012. The discourse of text messaging. Analysis of SMS communication. London \& New York: Continuum.

Thurlow, Crispin \& Cristine Mroczek. 2011. Fresh perspectives on new media sociolinguistics. In C. Thurlow \& K. Mroczek (eds.), Digital discourse. Language in the new media, xix-xliv. Oxford: Oxford University Press.

Torres-Pla, Joaquim. 2012. L'evolució dels usos privats a Catalunya del 1997 al 2008. Treballs de Sociolingüística Catalana 22. 27-40.

Torrijos, Anna. 2013. Les trajectòries lingüístiques de les persones joves a Catalunya. Direcció General de Política Lingüística. Generalitat de Catalunya. Presentation at the II Jornades 'La recerca sociolingüística en l'àmbit de la llengua catalana'. Xarxa Cruscat. Barcelona: Institut d'Estudis Catalans.

Woolard, Kathryn A. 2003. 'We don't speak Catalan because we are marginalized'. Ethnic and class connotations of language in Barcelona. In R. Blot (ed.), Language and social identity, 85-103. Westport: Praeger.

Woolard, Kathryn A. 2013. Is the personal political? Chronotypes and changing stances toward Catalan language and education. International Journal of Bilingual Education and Bilingualism 16(2). 210-224.

Woolard, Kathryn A. \& Susan E. Frekko. 2013. Catalan in the twenty-first century: Romantic publics and cosmopolitan communities. International Journal of Bilingual Education and Bilingualism 16(2). 129-137. 